Revue bibliographique pour le domaine irano-aryen

\title{
Pierre Briant. « Les tablettes de bois du Grand roi (Note sur les communications officielles dans un royaume itinérant)»
}

\section{Astrid Nunn}

\section{(2) OpenEdition} Journals

Édition électronique

URL : http://journals.openedition.org/abstractairanica/42560

DOI : 10.4000/abstractairanica.42560

ISBN : 1961-960X

ISSN : 1961-960X

Éditeur :

CNRS (UMR 7528 Mondes iraniens et indiens), Éditions de l'IFRI

\section{Référence électronique}

Astrid Nunn, «Pierre Briant. « Les tablettes de bois du Grand roi (Note sur les communications

officielles dans un royaume itinérant) » », Abstracta Iranica [En ligne], Volume 37-38-39 | 2018,

document 4, mis en ligne le 10 mars 2018, consulté le 28 septembre 2020. URL : http://

journals.openedition.org/abstractairanica/42560; DOI : https://doi.org/10.4000/abstractairanica. 42560

Ce document a été généré automatiquement le 28 septembre 2020.

Tous droits réservés 


\title{
Pierre Briant. « Les tablettes de bois du Grand roi (Note sur les communications officielles dans un royaume itinérant)»
}

\author{
Astrid Nunn
}

\section{RÉFÉRENCE}

Pierre Briant. « Les tablettes de bois du Grand roi (Note sur les communications officielles dans un royaume itinérant) ", in Michael Kozuh, Wouter F. M. Henkelman, Charles E. Jones, Christopher Woods (eds.). Extraction \& Control: Studies in Honor of Matthew W. Stolper. Studies in Ancient Oriental Civilization 68. Chicago, The Oriental Institute of the University of Chicago, 2014, p. 37-40.

Sachant aujourd'hui que le roi achéménide était souvent absent de Persépolis, l'A. trouve tentant de postuler l'usage de tablettes de bois. Ceci est bien possible, vue l'importance qu'elles avaient à la cour néo-assyrienne.

\section{AUTEURS}

ASTRID NUNN

Université de Munich 